\title{
FORMATAÇÃO DE TUTELAS ESPECÍFICAS E DOSAGEM DA AMPLITUDE DA COGNIÇÃO
}

\section{FORMATTING OF SPECIFIC PROTECTIVE MEASURES AND PROPORTION OF COGNITION SCOPE}

Odoné Serrano Júnior"

\begin{abstract}
Resumo: Partindo do pressuposto de que a tutela jurisdicional civil é expressão do direito fundamental de proteção, que exige o emprego da melhor técnica disponível no atual estado da arte, mostrar-se-á que as técnicas de formatação de tutelas específicas, implementadas a partir da possibilidade de combinação de provimentos e dos seus meios de efetivação, adequando-se às necessidades concretas do direito carente de tutela, somada à técnica da dosagem correta da amplitude da cognição judicial, contribuem sobremaneira para a racionalização da atividade jurisdicional, simplificando e acelerando o procedimento, importando, enfim, em ganhos em termos de efetividade.
\end{abstract}

Palavras-chave: Processo civil. Tutela específica. Cognição judicial. Técnicas processuais. Efetividade.

\begin{abstract}
This study starts from the premise that civil protective measures are the expression of the fundamental right to protection, and require the use of the best available technique in the current state of art. Its article will show that formatting techniques of specific protective measures, implemented by combining preventive measures and means for their effectiveness, adapted to the concrete needs of the right in need of protection, and added to the technique of correct proportion of legal cognition scope, contribute for the rationalization of the legal activity. Consequently, such techniques simplify and accelerate the procedure, causing gains in terms of effectiveness.
\end{abstract}

Keywords: Civil law. Specific protective measures. Legal cognition. Procedural techniques. Effectiveness.

Mestre pela Faculdade Estadual de Direito do Norte Pioneiro; Doutorando pela PUCPR. 


\section{A TUTELA JURISDICIONAL CÍVEL, DIREITO A PROTEÇÃO E AS TÉCNICAS PROCESSUAIS}

A tutela jurisdicional cível é expressão funcional do direito fundamental de proteção. Com efeito, há força de vinculação no modo de operar os instrumentos do processo civil, exigindo do Poder Judiciário o melhor manejo possível deles. Os direitos devem ser adequadamente protegidos. Para essa proteção, a tutela jurisdicional cível desempenha papel importante, na medida em que, regra geral, está proibida a justiça de mão própria. Nesse prisma, José Roberto dos Santos Bedaque enfatiza que o direito de ação deve ser visto como garantia de efetividade ${ }^{1}$, conferindo ao seu titular a possibilidade de exigir instrumentos aptos a solucionar as controvérsias de maneira adequada e útil. Às situações concretas apresentadas à apreciação do Poder Judiciário devem corresponder formas de tutelas idôneas a assegurar a realização dos direitos delas emergentes. $\mathrm{O}$ direito de agir em Juízo, assegurado em sede constitucional, não se exaure em si mesmo, devendo ser examinado em função da tutela pretendida, que deve ser efetiva, real e útil. $O$ que interessa para o cidadão é a possibilidade concreta de obter proteção ao seu direito substancial. (BEDAQUE, 2003).

Cumpre ressaltar que a dimensão funcional de direito de proteção, presente em todos os direitos fundamentais, vincula o modo de operar os instrumentos do processo civil, exigindo que o Poder Judiciário preste proteção mediante técnicas processuais eficientes. Há, assim, um dever de implementar pela via do processo civil a máxima proteção possível aos direitos fundamentais. Ao enfrentar uma situação concreta, deve se extrair do ordenamento jurídico todas as suas possibilidades de outorga de proteção aos direitos. Assim, por exemplo, independentemente da vigência ou não de uma norma penal, objeto de processo no Juízo Criminal, o Poder Judiciário pode cumprir o seu dever de direito de proteção a um direito fundamental, coibindo, num caso concreto, agressões de terceiros mediante expedição de ordens judiciais prolatadas por Juiz Cível (MORO, 2001), a serem implementadas mediante medidas coercitivas ou de sub-rogação.

Destacando a importância das tutelas inibitórias e preventivas executivas cíveis aos direitos fundamentais, Carmem Lúcia Antunes Rocha argumenta que "diversamente do que ocorre com outros direitos ou, principalmente,

${ }^{1}$ Bedaque (2003, p. 24) traz um bom conceito de efetividade: "Efetividade da tutela jurisdicional significa a maior identidade possível entre o resultado do processo e o cumprimento espontâneo das regras de direito material”. 
com outras agressões que ao direito impende resolver, os direitos fundamentais, pela sua própria natureza, não podem esperar para um deslinde que somente sobrevenha quando o bem jurídico é a vida, a liberdade ou a segurança, por exemplo, seja em suas manifestações diretas, seja em suas apresentações mediatas (o trabalhador que não receba o seu salário e fique sem condições de se alimentar é lesado no próprio direito à vida digna). Assim, as Constituições, como as normas de direito internacional relativas aos direitos fundamentais, enfatizam, na atualidade, a necessidade de se terem resguardados tais direitos no plano mesmo da ameaça. A prevenção é o melhor cuidado a se tomar, juridicamente, em casos de direitos fundamentais. Quanto mais eficientes forem os sistemas em dotarem os indivíduos e as instituições de instrumentos acautelatórios a fim de que ameaças sejam sustadas ou desfeitas antes mesmo da prática prejudicial aos direitos, tanto melhor atendidos estarão os objetivos dos ordenamentos jurídicos. A Constituição da República brasileira aperfeiçoou a qualidade dos instrumentos garantidores daqueles direitos ao estabelecer no art. 5 , inciso XXXV, que "a lei não poderá excluir da apreciação do Poder Judiciário lesão ou ameaça a direitos”. (ROCHA, 1996, p. 56).

Seguindo o mesmo diapasão, Luiz Guilherme Marinoni (2004, p. 82-83) assevera que

Uma Constituição que se baseia na "dignidade da pessoa humana" (art. 1" III) e garante a inviolabilidade dos direitos da personalidade (art. 5a, $\mathrm{X}$ ) e o direito de acesso à justiça diante de "ameaça a direito" (art. 5a , XXXV), exige a estruturação de uma tutela jurisdicional capaz de garantir de forma adequada e efetiva a inviolabilidade dos direitos não patrimoniais. - $\mathrm{O}$ direito fundamental à tutela jurisdicional efetiva - garantido pelo art. $5^{\mathrm{a}}$, XXXV, da $\mathrm{CF}$ - obviamente corresponde, no caso de direito não patrimonial, ao direito a uma tutela capaz de impedir a violação do direito. A ação inibitória, portanto, é absolutamente indispensável em um ordenamento que se funda na "dignidade da pessoa humana" e que se empenha em realmente garantir e não apenas em proclamar - a inviolabilidade dos direitos da personalidade. - Isso quer dizer que, se a propriedade pode ser protegida por meio de procedimentos especiais capazes de propiciar tutela preventiva, não há como negar igual formato aos direitos da personalidade, sob pena de desconsideração dos próprios valores constitucionais.

O bom domínio de técnicas processuais nos faz enxergar possibilidades até então ignoradas de o Poder Judiciário contribuir com a efetividade dos direitos fundamentais, mediante tutelas idôneas, adequadas às necessidades do caso concreto. $\mathrm{Na}$ seara das técnicas processuais cíveis, a doutrina brasileira 
apresenta-se em estágio avançado, tendo influenciado muitas reformas legislativas ${ }^{2}$, além de propor mudanças nos paradigmas de interpretação com vistas a melhorar a efetividade do processo civil, revelando novas possibilidades, num constante aprimoramento. A consolidação dessa empreitada, contudo, se dá com a assimilação da boa teoria pela prática do Judiciário. ${ }^{3}$

Kazuo Watanabe (1995), com sua peculiar precisão e poder de síntese, observou que a efetividade do processo como instrumento de tutela jurisdicional de direitos é uma das preocupações mais salientes dos processualistas contemporâneos. Em sua lúcida visão, para se atingir efetividade processual, mostram-se imprescindíveis: o aperfeiçoamento dos institutos e das técnicas processuais; a definição de procedimentos diferenciados; a aceleração e a simplificação dos procedimentos existentes; a antecipação da tutela; a dosagem adequada da amplitude e profundidade (intensidade) da cognição; a facilitação da prova; a facilitação do acesso à Justiça; o permanente aperfeiçoamento dos Juízes e a melhoria da infra-estrutura material e de pessoal dos órgãos jurisdicionais. Todas as observações acima estão corretas. Entretanto, o que gostaríamos de destacar é que, ao lado do aumento do número de juízes e da modernização da estrutura organizacional do Poder Judiciário a assimilação e do emprego de boas técnicas processuais contribui em muito com a melhora da efetividade da Jurisdição Cível na proteção dos direitos.

Por isso, neste capítulo, abordaremos as seguintes técnicas processuais que estão a serviço da eficaz proteção aos direitos, notadamente dos direitos fundamentais:

1) formatar tutelas específicas a partir das necessidades do direito material;

2) dosar adequadamente a amplitude da cognição judicial;

3) atender situações de urgência mediante tutela provisória que neutralize o fator de perigo;

4) dar tutela adequada aos direitos difusos e coletivos stricto sensu; e

5) dar tutela coletiva a direitos individuais homogêneos.

${ }^{2}$ A reforma do CPC de 1994 foi capitaneada por Sálvio de Figueiredo Teixeira e por Athos Gusmão Carneiro, reconhecidos doutrinadores do Processo Civil.

${ }^{3}$ Neste sentido, José Roberto dos Santos Bedaque (2003, p. 17), destaca que o bom funcionamento da técnica processual, por mais perfeita que possa parecer aos olhos dos processualistas, depende fundamentalmente das pessoas que a operam e da estrutura criada para a sua aplicação. Por isso, é preciso que as reformas processuais venham acompanhadas de alterações profundas na organização do Poder Judiciário, e com preocupações com a formação e aperfeiçoamento dos julgadores e serventuários da Justiça. 


\section{A TÉCNICA DE FORMATAR TUTELAS ESPECÍFICAS}

O uso de meios inadequados importará em prestação de tutela jurisdicional inadequada. Por isso, não se pode perder de vista o referencial das necessidades do caso concreto, das exigências e das peculiaridades do direito substancial carente de tutela. Ora, as técnicas de tutela jurisdicional somente podem ser reconhecidas como apropriadas quando se vincularem estritamente às necessidades do direito material. Vale dizer, a tutela jurisdicional, para ser efetiva, sempre deve ser específica, isto é, levar em conta as especificidades do direito material a ser satisfeito. Mas como é que se formata uma tutela específica? É o que responderemos a seguir.

A técnica de formatar tutelas específicas é feita a partir da possibilidade de combinação dos provimentos jurisdicionais e dos seus meios de efetivação para atender as necessidades concretas do direito material carente de tutela.

\subsection{Os provimentos jurisdicionais}

Os provimentos, para utilizar linguagem figurada, são as matérias-primas, são as cores, as tintas, que, combinadas ou não, irão compor o quadro de pintura da tutela jurisdicional, conforme a técnica mais adequada para atender as necessidades de proteção ao direito material. É com provimentos jurisdicionais, isolados ou combinados, que se formatam tutelas específicas.

Depois do artigo 84 da Lei 8.078/90 (Código de Defesa do Consumidor) e, principalmente depois da Lei 8.952/94, que deu nova redação ao artigo 461 do Código de Processo Civil, as posições de resistência de setores da doutrina - apegados a uma tradição já superada - com relação aos provimentos mandamentais e aos provimentos executivos efetivados no próprio processo de conhecimento, não mais se sustentam. Defasou-se a clássica classificação trinária das sentenças (declaratória, constitutiva e condenatória), como também foi colocada em xeque a idéia de que cognição e execução não poderiam fazer parte de um mesmo procedimento, pois não mais espelham (e talvez, a rigor, nunca espelharam) a realidade do sistema processual brasileiro. A recente Lei 11.232/2005 consolidou esse entendimento ao disciplinar expressamente a liquidação e a execução (cumprimento da sentença) como módulos procedimentais de uma mesma relação jurídica processual. Assim, não há mais dúvida de que, para tutelar adequadamente o direito material, a ordem jurídica disponibiliza ao juiz um leque de provimentos, identificados como declaratórios, constitutivos, "condenatórios", mandamentais e executivos. 
Há provimentos que têm eficácia restrita ao plano jurídico. São eles o declaratório, o constitutivo e o condenatório.

O provimento declaratório nada mais é do uma certificação oficial, tendo a função de eliminar qualquer questionamento plausível e admissível a respeito da existência ou não de uma relação jurídica, ou sobre o modo de ser de uma relação jurídica, ou ainda sobre a falsidade ou autenticidade de um documento. ${ }^{4}$ A atuação do provimento declaratório, assim, limita-se ao plano normativo. (ARENHART, 2003). Eventual repercussão no plano dos fatos se dá pelo atendimento espontâneo das partes ao que foi decidido por sentença.

O provimento constitutivo tem a finalidade de criar, modificar ou extinguir relação jurídica, sem trazer alteração no mundo sensível. Eventuais efeitos práticos da tutela constitutiva são reflexos, acidentais, irrelevantes ${ }^{5}$, pois ela opera apenas no plano normativo, no mundo jurídico. ${ }^{6}$

O provimento condenatório também opera exclusivamente no plano jurídico. A rigor, o que ocorre nos chamados "provimentos condenatórios", em essência, não é nada além de uma mistura de declaração e de constituição. Em sua dimensão declaratória, o "provimento condenatório" reconhece de

${ }^{4}$ Ensina Teori Albino Zavascki (2006, p. 245) que "A atividade jurisdicional exercida em qualquer processo de conhecimento visa a um objetivo específico: uma sentença de mérito. E em toda sentença de mérito há um componente essencial, de natureza declaratória: a declaração de certeza a respeito da existência ou da inexistência ou, ainda, do modo de ser de uma relação jurídica. Nela haverá, portanto, um juízo que contém "declaração imperativa de que ocorreu um fato ao qual a norma vincula um efeito jurídico". Realmente, as relações jurídicas têm sua existência condicionada à ocorrência de uma situação de fato (suporte fático) que atrai e faz incidir a norma jurídica. Esse fenômeno de incidência produz efeitos de concretização do direito, formando normas jurídicas individualizadas, contendo as relações jurídicas e seus elementos formativos: os sujeitos, a prestação, o vínculo obrigacional. Por isso se diz que, para chegar ao resultado almejado no processo de conhecimento (ou seja, ao juízo de certeza sobre a relação jurídica), é indispensável efetuar o exame "dos preceitos e dos fatos dos quais depende sua existência ou inexistência", e, "segundo os resultados desta verificação, o juiz declara que a situação existe ou que não existe". Trabalhar sobre as normas, os fatos e as relações jurídicas correspondentes é trabalhar sobre o fenômeno jurídico da incidência".

${ }^{5}$ Por exemplo, o divórcio pode tornar injustificável a cohabitação do casal; a anulação do contrato pode ensejar a devolução da coisa entregue, etc. Contudo, se não houver a observância espontânea pelas partes da nova situação jurídica criada pelo provimento constitutivo, será necessário o manejo de provimentos que atuem no plano dos fatos: os mandamentais e os executivos. 
maneira inquestionável a incidência de uma norma e de sua sanção respectiva, fazendo aplicar, concretamente, a norma abstrata que deverá reger a situação específica. Em sua dimensão constitutiva, o "provimento condenatório" cria o título executivo judicial. ${ }^{7}$ Criado esse título, estará autorizado o manejo de provimentos executivos e mandamentais e das técnicas de efetivação da decisão judicial por indução ou sub-rogação, visando realizar no mundo dos fatos o direito reconhecido no juízo de acertamento da controvérsia.

Antes da Lei 11.232/2005, a efetivação do provimento condenatório era feita, de regra, ex intervallo, em outro processo: o de execução de sentença. Com a Lei n. 11.232/2005, cuja vigência iniciou-se em 23.06.2006, deu-se maior celeridade ao cumprimento da sentença, abandonando o paradigma da autonomia do processo de execução de sentença condenatória, o qual passou a constituir mera fase do processo em que foi proferida a sentença, dispensando-se novo ato citatório para o início da execução. ${ }^{8}$ Rompeu-se, assim, de modo cabal, com a antiga idéia de que a cognição e a execução não podem ocorrer no mesmo processo. Com isso, tornou-se desatualizada a lição segundo a qual o provimento condenatório se efetiva ex intervallo, em outro processo, o de execução forçada.

Somente quando for preciso obter de alguém alguma prestação fática ou uma omissão é que surgirá a necessidade da tutela jurisdicional intervir no mundo concreto para efetivar-se. Se o que se necessita é obter de alguém um fazer, um dar (inclusive pagar), um não fazer ou um tolerar (permitir que outro faça), os provimentos declaratório, constitutivo e condenatório não se mostram suficientes. Devem ser buscados, então, provimentos que operem no plano dos fatos: o executivo e o mandamental.

O campo de aplicação dos provimentos executivos é restrito às prestações fungíveis.

O provimento executivo efetiva-se por meios sub-rogatórios de execução forçada, realizando o direito diretamente sobre o patrimônio do réu ou realizando o fato devido pelo réu por intermédio da atuação de terceiro, às

${ }^{6}$ Sérgio Cruz Arenhart (2003, p. 93-94) ensina que é constitutiva a tutela específica relativa à declaração de vontade (artigos 639 a 641 do CPC). Se alguém se obriga a prestar declaração de vontade e não o faz, pode a autoridade judiciária substituir-se à vontade do obrigado, suprindo a declaração faltante. Trata-se de tutela satisfativa que se opera no plano jurídico, não necessitando de ulterior execução.

${ }^{7}$ A respeito, vide Arenhart (2003, p. 94-96).

${ }^{8} \mathrm{~A}$ exceção à nova regra geral se dá para os casos em que não houve prévio processo civil perante órgão do Poder Judiciário brasileiro para a formação do título executivo judicial, nos quais haverá citação do devedor para liquidação e ou execução. 
expensas do réu. Tais meios sub-rogatórios podem operar inclusive por atuação do próprio Estado, por meio dos auxiliares do juízo, da força policial, etc.

O provimento mandamental, por seu turno, é constituído de uma determinação judicial (ordem, mandado) acompanhada de uma advertência de sanção (multa coercitiva, prisão civil, seqüestro de bens, suspensão temporária de direitos, indisponibilidade de bens, punição criminal por resistência (CP, art. 329), desobediência (CP, art. 330), prevaricação $(\mathrm{CP}$, art. 319) ou crime de responsabilidade (Decreto-lei 201/1967, art. 1르, XIV), punição civil por improbidade administrativa (Lei 8.429/92, art. 11, II e artigo 12, III), impeachment (CF, art. 85, VII), etc).

A sanção será aplicada somente se for verificado o descumprimento injustificado do decisum. A finalidade da advertência de sanção por descumprimento da ordem judicial é interferir no intelecto do réu para induzilo a cumprir a prestação ou a abstenção devida.

Os provimentos mandamentais servem tanto ao cumprimento dos deveres de não-fazer e de tolerar (que são sempre infungíveis), quanto ao cumprimento dos deveres de fazer fungíveis ou infungíveis.

\subsection{A efetivação de provimentos mandamentais e executivos: fungibilidade entre meios coercitivos e sub-rogatórios}

Na quadra atual do Processo Civil Brasileiro, universalizou-se a utilização de provimentos mandamentais e executivos e das medidas de efetivação por coerção indireta ou por sub-rogação?. Portanto, não há dúvida de que o Processo Civil Brasileiro oferece ao Juiz instrumentos idôneos para que ele dê tutela adequada e efetiva ao direito material lesado ou ameaçado de lesão, cumprindo o dever de proteção que decorre do direito fundamental à tutela jurisdicional efetiva previsto no artigo 5 $5^{\mathrm{a}}$, XXXV, da Carta Magna.

Há inquestionável fungibilidade entre tais provimentos e medidas de efetivação. Como efeito da fungibilidade, nada impede, por exemplo, que, após uma ordem sob pena de multa para que uma empresa pare de emitir seus dejetos tóxicos em um rio, verificado o não cumprimento da ordem e a ineficácia da multa como medida de coerção indireta, o Juiz determine o fechamento da indústria, fazendo cumprir essa decisão mediante utilização de força policial (substituição do provimento mandamental por executivo e aplicação de medida de efetivação por sub-rogação). (TESSLER, 2004).

\footnotetext{
${ }^{9}$ Vide as disposições do artigo 84 da Lei 8.078/90, dos artigos 287 e 461 do Código de Processo Civil e do artigo 11 da Lei 7.347/85, entre outros dispositivos de regência a casos específicos.
} 
Como há fungibilidade entre os provimentos mandamental e executivo e das medidas coercitivas e sub-rogatórias, constata-se que, para o Juiz, há uma margem de discricionariedade para elaborar a melhor técnica de efetivação da tutela jurisdicional em face de um caso concreto. A margem de liberdade do Juiz, entretanto, está condicionada à necessidade, à adequação e à proporcionalidade da medida eleita.

Cumpre aqui trazer à colação o preciso ensinamento de Humberto Ávila, segundo o qual o postulado da proporcionalidade se aplica em situações em que há uma relação de causalidade entre dois elementos discernidos empiricamente como um fim (estado de coisas que se procura atingir, resultado concreto ambicionado) e o meio para alcançá-lo, o qual deve ser adequado, necessário e proporcional. A estruturação exercida pelo postulado da proporcionalidade se dá mediante seus três exames fundamentais:

1) o da adequação ( $\mathrm{O}$ meio promove o fim?);

2) o da necessidade ou da proibição do excesso (Dentre os meios disponíveis e igualmente adequados para promover o fim, não há outro meio menos restritivo aos direitos fundamentais afetados?), e

3) o da proporcionalidade em sentido estrito (As vantagens trazidas pela promoção do fim justificam as desvantagens provocadas pela adoção do meio? Ou, em outros termos: $\mathrm{O}$ grau de importância da realização do fim justifica o grau de restrição que se causará aos direitos fundamentais?). (ÁVILA, 2004, p. 112-125).

No contexto da efetivação dos provimentos executivos, o legislador brasileiro adotou expressamente o postulado da proporcionalidade, ao dispor no artigo 620 do Código de Processo Civil que: "Quando por vários meios o credor puder promover a execução, o juiz mandará que se faça pelo meio menos gravoso para o devedor”. Assim, por exemplo, a interdição de uma fábrica poluidora pode se revelar medida excessiva, desproporcional e desnecessária quando se conseguir alcançar os mesmos resultados com a ordem de instalação de filtros. O mesmo preceito vale também para os provimentos mandamentais. Logo, o Juiz tem o dever de buscar o meio mais idôneo para atender ao direito em questão com a menor restrição possível aos direitos do réu. A decretação de prisão civil, diante da potencialidade lesiva a direitos fundamentais do réu, que será atingido direta e imediatamente em sua liberdade, só deve ser utilizada em casos extremos, com última alternativa, somente quando a ponderação cuidadosa dos dados concretos indicar ser tal medida imprescindível.

A multa coercitiva, por ser meio menos restritiva, é de mais larga utilização para efetivação dos provimentos mandamentais. A preferência pelo emprego 
da multa como medida coercitiva de efetivação de provimentos jurisdicionais foi explicitada pelo legislador no $\S 4^{\text {a }}$ do artigo 461 do Código de Processo Civil. Daí empregar-se a multa sempre que ela for "suficiente" para induzir ao cumprimento do preceito.

Não se confunde a multa coercitiva com a multa punitiva. Por exemplo: o inciso V, do artigo 14 do Código de Processo Civil, inserido pela Lei 10.358/ 2001 reza que "São deveres das partes e de todos aqueles que de qualquer forma participam do processo: [...] V - cumprir com exatidão os provimentos mandamentais”, prevendo, em seu parágrafo único, multa punitiva pelo ato atentatório ao exercício jurisdicional. ${ }^{10}$ Essa multa (punitiva) não se confunde com a multa coercitiva prevista pelos artigos 84 do Código de Defesa do Consumidor, 461 do Código de Processo Civil e 11 da Lei da Ação Civil Pública, razão pela qual pode haver incidência cumulada de ambas.

Com relação ao uso da punição criminal por resistência ou desobediência como medida coercitiva para fins de efetivação de provimento mandamental cível, deve-se observar que, atualmente, os tipos penais dos artigos 329 e 330 do Código Penal são considerados crimes de menor potencial ofensivo. ${ }^{11}$ Diante dessa incongruência, defendemos a necessidade de se aumentar o rigor na punição dos crimes de resistência e de desobediência (o que depende de reforma legislativa), bem como de se decretar prisão cível para os casos de não observância injustificadas das ordens judiciais, quando outras medidas menos gravosas mostrarem-se infrutíferas (o que depende apenas da correta interpretação do Direito), para não se esvaziar de efetividade os provimentos judiciais mandamentais.

${ }^{10}$ In verbis: "Ressalvados os advogados que se sujeitam exclusivamente aos estatutos da $\mathrm{OAB}$, a violação do disposto no inciso $\mathrm{V}$ deste artigo constitui ato atentatório ao exercício da jurisdição, podendo o juiz, sem prejuízo das sanções criminais, civis e processuais cabíveis, aplicar ao responsável multa em montante a ser fixado de acordo com a gravidade da conduta e não superior a vinte por cento do valor da causa; não sendo pago no prazo estabelecido, contado da data do trânsito em julgado da decisão final da causa, a multa será inscrita sempre como dívida ativa da União ou do Estado”.

${ }^{11}$ Clayton Maranhão (2003, p. 140) e Eduardo Talamini (2001, p. 307-314) destacam que esta situação faz diminuir, em razoável proporção, a efetividade do provimento mandamental. 


\subsection{A prisão civil como medida coercitiva indireta: Possibilidade de utilização, embora restrita a casos extremos, observadas as regras da proporcionalidade, adequação e necessidade da medida}

A admissibilidade da utilização da prisão civil como medida coercitiva para fins de cumprimento de provimentos jurisdicionais mandamentais já está consagrada para o cumprimento de obrigação alimentar, em caso de inadimplemento voluntário e inescusável, e para o depositário infiel. O Texto Constitucional é expresso em admitir sua admissibilidade para esses dois casos no dispositivo que trata da vedação da prisão civil por dívida (artigo 5 ${ }^{\underline{a}}$, LXVII).

Há uma corrente doutrinária que defende uma interpretação restritiva, segundo a qual a utilização da prisão civil somente seria admissível para essas duas hipóteses: alimentos e depositário infiel. Parte dos Juízes e Tribunais têm adotado essa interpretação restritiva. Não nos filiamos a este entendimento. Para nós, a possibilidade da utilização legítima da prisão civil não fica restrita a essas duas hipóteses, mas a qualquer caso de descumprimento injustificável de decisão judicial, principalmente daqueles que versem sobre direitos nãopatrimoniais, embora com características de excepcionalidade, isto é, como última alternativa.

A respeito, Pedro Lenza lembra que, por ocasião da discussão do projeto de Lei 3.475/2001, convertido na Lei $10.353 / 2001$, houve uma proposta no âmbito do Ministério da Justiça de previsão expressa da prisão civil como medida de coerção indireta para induzir ao cumprimento dos provimentos mandamentais e à não criação de embaraços à efetivação dos provimentos judiciais, antecipados ou finais, nos moldes da contempt of court do direito anglo-americano. Segundo essa proposta, se inseriria um $\S 2^{2}$ no artigo 14 do Código de Processo Civil, com a seguinte redação: "Se o responsável, no caso do parágrafo anterior, devidamente advertido, ainda assim reitera a conduta atentatória ao exercício da jurisdição, o juiz poderá impor-lhe prisão civil de até trinta dias, que será revogada quando cumprida a decisão judicial”. Tal proposta não foi levada à apreciação do Congresso Nacional em virtude de pressões da Casa Civil. (LENZA, 2005).

Embora a previsão expressa em dispositivo legal facilite o trabalho de vencer a resistência doutrinária e jurisprudencial, tendo, por isso, grande utilidade, ela não é imprescindível. Para nós, a interpretação sistemática do ordenamento jurídico em vigor, por si só, é capaz de revelar a possibilidade de o Juiz, na quadra atual, utilizar-se do mecanismo da prisão civil como medida de coerção indireta de cumprimento de decisão judicial, não se 
restringindo aos casos de obrigação alimentar ou do depositário infiel. O $\S 5^{\underline{a}}$ do artigo 461 do Código de Processo Civil e o $\S 5^{\text {a }}$ do artigo 81 do Código de Defesa do Consumidor, em vigor, já dão o respaldo normativo necessário ao manejo da prisão civil para induzir ao cumprimento de qualquer ordem judicial, notadamente para proteger direitos não-patrimoniais. Logo, não é preciso inovar o ordenamento jurídico mediante interpositio legislatoris.

Há limite, é claro, para a utilização dessa medida extrema. Contudo, o limite não vem da enumeração numerus clausus das hipóteses de cabimento da prisão civil no mencionado dispositivo da Constituição Federal, mas sim da aplicação dos postulados da proporcionalidade e da razoabilidade. Nesse sentido, é a opinião de juristas da mais alta envergadura.

$\mathrm{Na}$ visão de Luiz Guilherme Marinoni (1996, p. 87-8):

Não é errado imaginar que, em alguns casos, somente a prisão poderá impedir que a tutela seja frustrada. A prisão, como forma de coação indireta, pode ser utilizada quando não há outro meio para a obtenção da tutela específica ou do resultado prático equivalente. Não se trata, por óbvio, de sanção penal, mas de privação da liberdade tendente a pressionar o obrigado ao adimplemento. Ora, se o Estado está obrigado a prestar a tutela jurisdicional adequada a todos os casos conflitivos concretos, está igualmente obrigado a usar os meios necessários para que as suas ordens (o seu poder) não fique à mercê do obrigado. Não se diga que essa prisão ofende direitos fundamentais da pessoa humana, pois, se tal fosse verdade, não se compreenderia a razão para a admissão do emprego desse instrumento nos Estados Unidos, na Inglaterra e na Alemanha. Na verdade, a concepção de um processo como instrumento posto à disposição das partes é que encobre a evidência de que o Estado não pode ser indiferente à efetividade da tutela jurisdicional e à observância do ordenamento jurídico. Se o processo é, de fato, instrumento para a realização do poder estatal, não há como negar a aplicação da prisão quando estão em jogo a efetividade da tutela jurisdicional e o cumprimento do ordenamento jurídico. É por isso, aliás, que a Constituição não veda esse tipo de prisão, mas apenas a prisão por dívida.

Segundo o entendimento de Marcelo Lima Guerra (1998, p. 245-6):

Realmente, encarada a prisão civil como um importante meio de concretização do direito fundamental à tutela efetiva e não apenas como uma odiosa lesão ao direito de liberdade, uma exegese que restrinja a vedação do inc. LXVII do art. 5 da CF aos casos de prisão por dívida, em sentido estrito preserva substancialmente a garantia que essa vedação representa, sem eliminar totalmente as possibilidades de se empregar a prisão civil como medida coercitiva para assegurar a prestação efetiva da tutela jurisdicional. - Sendo assim, é razoável 
entender que o $\S 5^{\underline{a}}$ do art. 461 constitui fundamento legal bastante para que o juiz possa decretar a prisão de devedor de obrigação não pecuniária, como medida destinada a compeli-lo a adimplir, sempre que essa medida se revele a mais adequada, dentro dos critérios já examinados, ao caso concreto.

Para Sérgio Shimura (2001, p. 674), “é preciso interpretar a prisão como forma de concretização do direito fundamental à tutela efetiva, e não apenas como uma odiosa lesão ao direito de liberdade. Realmente, a prisão, no caso, nada tem a ver com dívida. Trata-se de meio coercitivo para cumprimento das determinações judiciais". Em face da alusão à "força policial”, feita no $\S 5^{\underline{a}}$ do artigo 461 do CPC, não se pode imaginar que qualquer pessoa do povo possa prender em flagrante delito algum transgressor, mas o juiz cível ou trabalhista, imbuído de seu ofício jurisdicional-constitucional, não o possa fazê-lo, tendo que presenciar "impávido a desobediência, a chicana, o atentado ao exercício legítimo da jurisdição, em incrédulo ostracismo sócio-político, contentandose com a vetusta, porém risível, remessa de peça materializadora da infração ao Ministério Público, a fim de que apure, em melodioso processo criminal, a responsabilidade do malsinado recalcitrante, que terminará por findar como tantas quimeras jurídicas”. Se o Processo Civil "já prevê a prisão pela recalcitrância e desacato à Justiça quando, por exemplo, alguém resista à ordem de penhora (art. 662 do CPC), quando o portador do título se recusa injustificadamente a devolvê-lo (art. 885 do CPC), ou, ainda, se o falido descumprir algum dos deveres previstos em lei (art. 35 do Dec.-lei 7.661/45)”, pela mesma razão esse meio coercitivo deve ser empregado para induzir ao cumprimento de todos os demais provimentos judiciais mandamentais. "Sem prejuízo desta forma de coerção indireta - prisão -, pode ficar caracterizado o crime de desobediência (art. 330 do CP), prevaricação (art. 319 do CP) ou mesmo de responsabilidade (art. 85 da CF; Dec.-lei 201/67). Mas, nesses casos, compete ao juízo com competência criminal para decretar a prisão, como sanção penal. "Não reinterpretar o processo como instrumento de efetivação do poder estatal e concretização do direito material da parte é permitir a desmoralização da Justiça, deixando o Judiciário totalmente manietado ao sabor do capricho do requerido". (SHIMURA, 2001, p. 674-5).

Partilhamos dessa interpretação e entendemos ser possível a adoção da prisão civil para induzir ao cumprimento da decisão judicial, como também para inibir a criação de embaraços à efetivação de provimentos judiciais, sempre que medidas menos gravosas não se revelarem aptas a tal desiderato e a parte, devidamente advertida, continuar recalcitrante. Como se trata de uma medida extrema, deverá existir observância rigorosa ao princípio da proporcionalidade, de modo a aplicá-la apenas como última alternativa. 


\subsection{Exemplos de modalidades de tutelas específicas}

O estudo dos meios só se justifica na medida em que contribua para se atingir resultados mais efetivos. Eis a razão para se estudar a técnica de formatação de tutelas específicas. Conjugando-se provimentos declaratórios, constitutivos, condenatórios, executivos e mandamentais, é possível efetivar tutelas específicas de diversas modalidades. A formatação de tutelas específicas deve atender às peculiaridades da situação de direito material carente de proteção. $\mathrm{O}$ objetivo é buscar o máximo de efetividade possível à proteção via tutela jurisdicional. A seguir, abordaremos exemplos, já identificados pela doutrina, de tutelas específicas que podem ser formatadas: a tutela inibitória, tutela preventiva executiva, tutela de remoção de ilícito ou reintegratória, tutelas de ressarcimento de danos e a tutela punitiva cível.

A tutela inibitória tem como pressuposto exclusivamente a iminência da prática de um ilícito (ou de sua repetição ou continuação), não se preocupando com o dano ou com a culpa, que são dados que ficam de fora do thema probandum et decidendum. Portanto, dano ou culpa não são objetos de cognição judicial neste tipo de tutela. Preocupar-se com dano e culpa em lide que envolve exclusivamente tutela inibitória importará em desperdício de atividade processual, notadamente de atos instrutórios, pela não dosagem adequada da cognição judicial quanto à amplitude (limitação no plano horizontal). Portanto, deve haver uma filtragem para que assuntos alheios ao thema probandum et decidendum, não façam parte da colheita de provas. Daí a importância da correta fixação dos pontos controvertidos e deliberação sobre as provas relevantes, pertinentes e úteis a serem produzidas, tal qual determinado pelo $\S 2^{\underline{a}}$ do artigo 331 do Código de Processo Civil. Para sua efetivação, a tutela inibitória vale-se de provimentos mandamentais e dos meios de coerção indireta para cumprimento da decisão judicial.

A tutela preventiva executiva, embora também vise prevenir a prática ou repetição de um ilícito futuro, apenas ameaçado, caracteriza-se (e se diferencia da tutela inibitória) por vir assistida por técnicas de sub-rogação. (MARANHÃO, 2003; MARINONI, 2000). Assim, por exemplo, a designação de um Oficial de Justiça para, com o auxílio de força policial, impedir a realização de uma festa na qual participaria uma multidão de pessoa, em área de especial proteção ambiental, caracteriza tutela preventiva executiva de ilícitos ambientais.

A tutela de remoção do ilícito é também chamada de tutela reintegratória. Trata-se de tutela repressiva, post factum, que busca a supressão do ilícito, isto é, visa o retorno ao status quo ante. ${ }^{12}$ A tutela de remoção do ilícito é 
tutela de repressão do ilícito e de prevenção do dano. A respeito dessa modalidade de tutela, Luiz Guilherme Marinoni (2004) cunhou expressão que bem descreve o objetivo colimado: "Remover o ilícito é secar a fonte dos danos” (p. 69). Ela pressupõe a demonstração de que foi praticado um ilícito que se perdura no tempo, que é o que a distingue da tutela de reparação dos danos in natura.

Um exemplo ilustra a diferença entre a tutela reintegratória (de remoção do ilícito) e a tutela de reparação dos danos: A exposição de lixo tóxico ao ambiente é um ilícito que gera constante violação à norma, sendo objeto de tutela de remoção do ilícito que se concretiza pela retirada do lixo do ambiente e seu acondicionamento adequado. Já no caso de vazamento de óleo ao mar, ao contrário, a prática do ilícito decorre de um único ato. Ato este que já se exauriu. O que persiste no tempo são os seus efeitos, isto é, os danos resultantes, que devem ser objeto de outro tipo de tutela: a de ressarcimento do dano.

A tutela de remoção do ilícito também prescinde da demonstração da culpa ou de dano, sendo esses dados irrelevantes, não fazendo parte do thema decidendum desta modalidade de tutela.

Por seu turno, as tutelas de ressarcimentos buscam a reparação de danos. Elas oferecem uma solução a posteriori factum que têm por objetivo recompor a situação anterior (status quo ante). Pode se dar por reparação específica (in natura), por compensação (resultado prático equivalente) ${ }^{13}$ ou pelo equivalente pecuniário ${ }^{14}$.

${ }^{12}$ A tutela do adimplemento é também de remoção de um ilícito (a mora), por meio do cumprimento, ainda que extemporâneo, da prestação devida.

${ }^{13}$ Luciane Gonçalves Tessler (2004, p. 371) traz a lume dois exemplos de compensação ecológica alinhavados em âmbito judicial. O primeiro deles ocorreu em Florianópolis, onde um projeto de urbanização balneária na praia de Jurerê causou danos ao Rio do Meio. O Ministério Público pediu judicialmente a reabertura do rio e a questão foi resolvida por compensação ecológica, realizado termo de ajustamento de conduta no qual a ré, Habitasul, construiu um lago com superfície superior a $32.000 \mathrm{~m} 2$, para a captação de águas pluviais, com a substituição de uma das finalidades do Rio do Meio e, como a compensação era parcial, comprometeu-se a pagar indenização de setenta e cinco mil reais à Secretaria do Meio Ambiente, Migração e Habitação do Município de Palhoça, a ser revertida para o Parque Ecológico Municipal no Manguezal. O segundo exemplo ocorreu em Belo Horizonte, em demanda movida contra a Fiat, que foi acusada de lançar no mercado veículos que emitiam poluentes acima do nível estabelecido em lei, ao ter substituído o catalisador por dispositivo eletrônico que não tinha a mesma eficiência. Em acordo com o Ministério Público Federal a multa que a empresa deveria pagar à União foi substituída por medidas compensatórias, 
A tutela punitiva não é exclusiva da jurisdição penal. Há também tutela punitiva que se opera na jurisdição cível, com aplicação de sanções, como multa, suspensão de direitos, etc., a título de reprovação pela prática de um ilícito, a exemplo das disposições do artigo 12 da Lei 8.429/92 que prevê sanções punitivas à prática de atos de improbidade administrativa. ${ }^{15}$

\subsection{Tutelas específicas e os direitos fundamentais}

Em se tratando de direitos fundamentais, ligados à proteção da dignidade da pessoa humana, a tutela específica adequada não é a reparatória pelo equivalente pecuniário, pois de modo algum com ela se compensaria adequadamente os prejuízos causados, eis que o valor desses direitos não se mede pelo metro da pecúnia, nem são passíveis de conversão em moeda. A base dos direitos fundamentais é a proteção da dignidade da pessoa humana, e a dignidade, como sabemos, não tem preço. Logo, o que importa é, em primeiro lugar, impedir a lesão. Somente quando não for mais possível impedir a lesão é que buscará colocar o titular do direito na mesma posição em que estaria se não tivesse havido a violação do seu direito, mediante remoção do

obrigando-se a empresa a doar 6.000 hectares ao Ibama, prover toda a estrutura para transformar a área no Parque Nacional do Vale do Peraçu, além de ter que doar um laboratório de análise de emissões atmosféricas, um veículo de monitoramento da qualidade do ar e outros equipamentos para o órgão ambiental. Por seu turno, Carlos Alberto Salles (1998, p. 307-309) observa com propriedade que as indenizações destinadas ao chamado "Fundo de Recuperação dos Bens Lesados", previstas no artigo 13 da Lei $7.347 / 85$, nos casos de danos ambientais, quando se estiver diante da completa impossibilidade de reconstituição dos bens lesados, não tem o sentido de ressarcimento específico, in natura, mas sim constituem medidas de natureza compensatória.

${ }^{14}$ Os artigos 84, caput e $\S 1^{\underline{a}}$, do Código de Defesa do Consumidor, 461, caput e $\S 1^{\underline{a}}$ do Código de Processo Civil e artigo 11 da Lei da Ação Civil Pública indicam que a tutela de ressarcimento in natura tem primazia sobre a tutela de ressarcimento pelo equivalente pecuniário. Aliás, em se tratando de direitos não-patrimoniais, como o meio ambiente, a saúde pública, etc., impossível é a conversão em pecúnia. As indenizações revertidas aos Fundos de Recuperação dos Bens Lesados constituem técnica de operacionalização de uma compensação, quando impossível a tutela de reparação in natura, pois visa obter resultados práticos equivalentes.

${ }^{15}$ A respeito, Teori Albino Zavascki (2006, p. 109) leciona que: "Não há dúvida de que as sanções aplicáveis aos atos de improbidade, previstas na Lei 8.429/92, não têm natureza penal. Todavia, há inúmeros pontos de identidade entre as duas espécies, seja quanto à sua função (que é punitiva e com finalidade pedagógica e intimidatória, 
ilícito ou reparação do dano in natura ou pelo resultado prático equivalente. Daí a importância de se trabalhar com provimentos jurisdicionais que atuem no plano dos fatos. Na proteção dos direitos fundamentais, portanto, a utilidade dos provimentos executivos e mandamentais e de seus meios de efetivação coercitivos ou sub-rogatórios, aptos a provocar efeitos de mudança no plano da realidade fática ou de impedir tais mudanças, se sobressai.

Vê-se, portanto, que a proteção a direitos fundamentais demanda a formatação de tutelas que contemplem provimentos mandamentais e executivos, efetivados prontamente por meios de coerção indireta ou de subrogação, de modo a conseguir, de forma rápida a prevenção de ilícito, a remoção do ilícito ou a reparação dos danos in natura ou pelo resultado equivalente.

\section{A TÉCNICA DE DOSAR CORRETAMENTE A AMPLITUDE DA COGNIÇÃO JUDICIAL}

O estabelecimento de tutelas diferenciadas, congruentes às necessidades do caso concreto, constitui medida importante de racionalização da atividade jurisdicional, simplificando e acelerando o procedimento. Contudo, de nada adianta a correta formação de tutelas específicas se esta for anulada no decorrer

visando a inibir novas infrações), seja quanto ao conteúdo. Com efeito, não há qualquer diferença entre a perda da função pública ou a suspensão dos direitos políticos ou a imposição de multa pecuniária, quando decorrente de ilícito penal e de ilícito administrativo. Nos dois casos, as conseqüências práticas em relação ao condenado serão absolutamente idênticas. A rigor, a única diferença se situa em plano puramente jurídico, relacionado com efeitos da condenação em face de futuras infrações: a condenação criminal, ao contrário da não-criminal, produz as conseqüências próprias do antecedente e da perda da primariedade, que podem redundar em futuro agravamento de penas ou, indiretamente, em aplicação de pena privativa de liberdade (CP, arts. 59; 61, I; 63; 77, I; 83, I; 110; 115, § 2 $2^{\underline{a}}$ e 171, § 1ํㅡ). Quanto ao mais, entretanto, não há diferença entre uma e outra. Somente a pena privativa de liberdade é genuinamente criminal, por ser cabível unicamente em casos de infração penal. A prisão civil, nas hipóteses admitidas pela Constituição ("inadimplemento voluntário e inescusável de obrigação alimentícia e a do depositário infiel” - art. 5aㅡ, LXVII), não é pena, mas simples meio executivo para compelir o devedor a cumprir a obrigação: atendida a prestação, cessa a medida constritiva, mesmo que decretada por prazo maior. Assim, excetuada a pena privativa de liberdade, qualquer outra das sanções previstas no artigo $5^{\mathrm{a}}$, XLVI, CF, pode ser cominada tanto a infrações penais, quanto a infrações administrativas, como ocorreu na Lei 8.429/92". 
do processamento pela não dosagem adequada da amplitude da cognição judicial. Como os requisitos de cada tutela são diferentes - por exemplo, para a tutela inibitória as considerações a respeito de culpa são impertinentes -, é desnecessário gastar tempo e recursos materiais com discussões e com produções de provas sobre pontos impertinentes, que não fazem parte do thema probandum et decidendum. Basta que a amplitude da cognição judicial seja adequadamente limitada ${ }^{16}$. Eis aí a relevância da correta aplicação da norma explicitada pelo $\S 2^{\underline{a}}$ do artigo 331, pelo inciso II do artigo 125 e pelo artigo 130, todos do Código de Processo Civil a exigir que o Juiz fixe corretamente os pontos controvertidos, determine a realização das provas necessárias à instrução do processo e indefira os requerimentos de diligências probatórias inúteis ou meramente protelatórias.

Qualquer prova que seja produzida a respeito de elementos que não se relacionam com o objeto da tutela configurará cognição inadequada do direito material, importando em postergação indevida da atividade jurisdicional e desperdício de tempo e de recursos públicos. Saliente-se que a ampliação desnecessária do âmbito cognitivo pode significar frustração da tutela jurisdicional no momento oportuno e, Justiça que tarda muitas vezes é Justiça que falha. Portanto, o bom uso da técnica de correta dosagem da amplitude da cognição judicial de acordo com os elementos relevantes da tutela específica tratada no caso concreto é fator decisivo para a melhora de desempenho e para assegurar efetividade à função jurisdicional.

\section{REFERÊNCIAS}

ARENHART, Sérgio Cruz. Perfis da tutela inibitória coletiva. São Paulo: Ed. Revista dos Tribunais, 2003.

ÁVILA, Humberto. Teoria dos princípios: da definição à aplicação dos princípios jurídicos. 3. ed. São Paulo: Malheiros, 2004.

BEDAQUE, José Roberto dos Santos. Tutela cautelar e tutela antecipada: tutelas sumárias e de urgência (tentativa de sistematização). 3. ed. São Paulo: Malheiros, 2003.

${ }^{16}$ Como bem adverte Teori Albino Zavascki (2005, p. 22), cognição exauriente não é sinônimo de cognição ilimitada, mas sim de cognição formada à base dos meios de contraditório e de defesa adequados ao objeto cognoscível. 
GUERRA, Marcelo Lima. Execução indireta. São Paulo: Ed. Revista dos Tribunais, 1998.

LENZA, Pedro. Teoria geral da ação civil pública. 2. ed. São Paulo: Ed. Revista dos Tribunais, 2005.

MARANHÃO, Clayton. Tutela jurisdicional do direito à saúde: (arts. 83 e 84, CDC). São Paulo: Revista dos Tribunais, 2003.

MARINONI, Luiz Guilherme. Novas linhas do processo civil. 2. ed. São Paulo: Malheiros, 1996.

. Técnica processual e tutela dos direitos. São Paulo: Ed. Revista dos Tribunais, 2004.

. Tutela específica: (arts. 461, CPC e 84, CDC). São Paulo: Ed. Revista dos Tribunais, 2000.

MORO, Sergio Fernando. Desenvolvimento e efetivação judicial das normas constitucionais. São Paulo: Max Limonad, 2001.

ROCHA, Carmem Lúcia Antunes. O constitucionalismo contemporâneo e a instrumentalização para a eficácia dos direitos fundamentais. Revista Trimestral de Direito Público, São Paulo, n. 16, p. 39-58, 1996.

SALLES, Carlos Alberto. Execução judicial em matéria ambiental. São Paulo: Ed. Revista dos Tribunais, 1998.

SHIMURA, Sérgio. Efetivação das tutelas de urgência. In: SHIMURA, Sérgio; WAMBIER, Tereza Arruda Alvim (Coord.). Processo de Execução, p. 665-684. São Paulo: Ed. Revista dos Tribunais, 2001. p. 674-675.

TALAMINI, Eduardo. Tutela relativa aos deveres de fazer e de não fazer: CPC, art. 461; CDC, art. 84. São Paulo: Ed. Revista dos Tribunais, 2001.

TESSLER, Luciane Gonçalves. Tutelas jurisdicionais do meio ambiente: tutela inibitória, tutela de remoção, tutela do ressarcimento na forma específica. São Paulo: Ed. Revista dos Tribunais, 2004.

WATANABE, Kazuo. Apontamentos sobre: "Tutela jurisdicional dos interesses difusos (necessidade de processo dotado de efetividade e de aperfeiçoamento permanente dos Juízes e apoio dos órgãos superiores da Justiça em termos de infra-estrutura material e pessoal)”. In: MILARÉ, Édis (Coord.). Ação Civil Pública: Lei 7.347/85 - Reminiscências e Reflexões após dez anos de aplicação. 
São Paulo: Ed. Revista dos Tribunais, 1995.

ZAVASCKI, Teori Albino. Antecipação da tutela. 4. ed. São Paulo: Saraiva, 2005.

- Processo coletivo: tutela de direitos coletivos e tutela coletiva de direitos. São Paulo: Ed. Revista dos Tribunais, 2006.

Tutela de direitos coletivos e tutela coletiva de direitos. São Paulo:

Ed. Revista dos Tribunais, 2006. 